\title{
The Effect of Computer-Assisted Glycemic Monitoring Protocol on Workload of Intensive Care Nurses $\infty$
}

\author{
Özlem CANBOLAT ${ }^{1}$, Sevgisun KAPUCU ${ }^{2}$
}

\begin{abstract}
Aim: This study aimed to determine the effect of using a computerassisted glycemic monitoring protocol on the workload of intensive care nurses.

Material and Methods: This quasi-experimental study was conducted with intensive care unit nurses $(n=19)$. The time spent by the nurses during glycemia follow-up was recorded by two observer nurses using stopwatches. Glycemic monitoring was performed using a computerized and written protocol. After the application part of the research, the opinions of the nurses about the protocols were evaluated with a questionnaire form.

Results: While the mean time spent on glycemia follow-up using the computerized protocol was $30.5 \pm 8.18$ seconds, the mean time spent using the written protocol was $42.7 \pm 10.04$ seconds ( $p<$ $0.001) .78 .9 \%$ of nurses stated that written protocol was more complicated, $78.9 \%$ computerized protocol more suitable for intensive care unit, and $78.9 \%$ satisfied with using the computerized protocol.

Conclusion: The use of the computerized protocol was shown to be effective in reducing the workload of intensive care nurses. The computerized protocol has increased nurse satisfaction in caring for patients with hyperglycemia who need intravenous insulin management.

Keywords: Computer-assisted protocol, glycemic control, intensive care, nursing workload.
\end{abstract}

\section{öz}

Bilgisayar Destekli Glisemi Takip Protokolünün Yoğun Bakım Hemşirelerinin İş Yüküne Etkisi

Amaç: Bu çalışmanın amacı bilgisayar destekli glisemi takip protokolü kullanımının yoğun bakım hemşirelerinin iş yüküne etkisini belirlemektir.

Gereç ve Yöntem: Bu yarı deneysel çalışma yoğun bakım ünitesinde çalışan hemşireler ile yapılmıştır ( $n=19)$. Hemşirelerin glisemi takibi sırasında harcadıkları süre 2 gözlemci hemşire tarafından kronometre kullanılarak kaydedilmiştir. Glisemi takibi bilgisayarlı ve yazıı protokol kullanılarak yapılmıştır. Araştırmanın uygulama kısmından sonra hemşirelere protokoller hakkındaki görüşleri anket formu ile değerlendirilmiştir.

Bulgular: Bilgisayarlı protokol kullanarak yapılan glisemi takibi sırasında harcanan süre ortalama $30.5 \pm 8.18$ saniye iken, yazılı protokol kullanılarak glisemi takibi sırasında harcanan süre ortalama $42.7 \pm 10.04$ saniye bulunmuştur $(p<0.001)$. Hemşirelerin \%78.9'u yazılı protokolün daha karmaşık olduğunu, \%78.9'u bilgisayarlı protokolün yoğun bakım için uygun protokol olduğunu ve \%78.9'u bilgisayarlı protokolü kullanmaktan memnun olduğunu belirtmiştir.

Sonuç: Bilgisayar destekli glikoz yönetim protokolü kullanımının, yoğun bakım hemşirelerinin iş yükünü azaltmada etkili olduğu gösterilmiştir. Bilgisayarlı protokol, intravenöz insülin yönetimine ihtiyaç duyan hiperglisemi hastalarının bakımında hemşire memnuniyetini artırmıştır.

Anahtar kelimeler: Bilgisayar destekli protokol, glisemik kontrol, hemşire iş yükü, yoğun bakım

${ }^{1}$ Assistant Professor, Gazi University Faculty of Health Sciences School of Nursing, Ankara, Turkey, E-mail: ozlemcanbolat06@gmail.com, Phone: +90 0312 216 26 23, ORCID: 0000-0002-4222-4577

${ }^{2}$ Professor, Hacettepe University Faculty of Nursing Department of Internal Medicine Nursing, Ankara, Turkey. E-mail: sevgisunkapucu@gmail.com, Phone: +90 312305 1580, ORCID: 0000-0003-3908-3846

Geliş Tarihi: 28 Eylül 2020, Kabul Tarihi: 02 Eylül 2021

*This study presented at 11-12th December 2017 of ICAPN 2017:19th International Conferance on Advanced Practice Nursing, Roma, Italy as oral presentation (P.663).

Atıf/Citation: Canbolat Ö., Kapucu S. The Effect of Computer-Assisted Glycemic Monitoring Protocol on Workload of Intensive Care Nurses. Journal of Hacettepe University Faculty of Nursing 2021;8(3):293-298. DOI: 10.31125/ hunhemsire.1050387 


\section{INTRODUCTION}

Hyperglycemia (blood glucose level $>180 \mathrm{mg} / \mathrm{dL}$ ) is common in critically ill patients in intensive care units ${ }^{1}$. Hyperglycemia in critically ill patients leads to increased mortality and morbidity2-8. Hypoglycemia, a complication arising from hyperglycemia treatment, can cause fatal outcomes for patients. Glucose follow-up protocols are used to protect intensive care patients from hyperglycemia, a risk factor associated with negative outcomes caused by surgical and medical conditions. Studies in the literature show that glucose follow-up using these protocols reduces mortality and morbidity ${ }^{9-13}$

It is extremely important that intensive care nurses, who are responsible for the care and treatment of critical patients, closely monitor any changes that may occur in the patients so that they can intervene immediately. Intensive care nurses who are involved in the prevention of hyperglycemia or hypoglycemia, which require close monitoring and intervention in patients, need a well-developed "glucose monitoring system" for glucose control. The ideal glucose follow-up protocol for glucose control in intensive care patients should prevent the development of hyperglycemia and hypoglycemia and provide successful glucose control in a short time ${ }^{14,15}$. In the literature, many glucose follow-up protocols have been prepared and published within the framework of evidence-based approaches ${ }^{10,16-19}$.

Nowadays, within the framework of the possibilities offered by developments in the IT sector, written protocols can be turned into computer-guided software to reduce employee workload and prevent medical errors that may arise owing to humans. Many nursing care services are carried out by the nurses who provide care for critical illnesses in intensive care units and owing to their high workload the patient safety is at risk ${ }^{20}$. Computer-guided protocols developed for exactly this reason should enable intensive care unit (ICU) nurses to make quick clinical decisions accurately and successfully, without increasing their workload ${ }^{14,15}$

In a study by Newton et al., it was found that glucose followup using an insulin infusion protocol developed as a computer program used by nurses helped to achieve the target glucose level in a shorter time than the written protocol $^{21}$. Olinghouse showed that calculation of the patient's insulin dose took 30 seconds using the computerguided protocol and 2 minutes with the written protocol ${ }^{22}$. Studies have shown that the computer-guided protocol led to less hypoglycemia than the written protocol, which is why nurses found it safer, easier to use, and more effective compared with the written protocol ${ }^{23,24}$. Canbolat et al. found that intensive care nurses think that computerguided glucose follow-up protocols are more effective, safer, and easier than the routine practice. They also stated that the use of a computerized protocol is more appropriate for intensive care settings ${ }^{25}$.

Studies evaluating the effect of computerized protocols on workload are limited worldwide and no studies on this topic have been carried out in Turkey. We believe that in order to increase the applicability of a protocol, not only its effectiveness and reliability but also its effect on staff workload must be analyzed. For this reason, this study was planned to determine the effect of a computer-guided glucose management protocol we developed in 2016 for efficacy and reliability for patients on the workload of intensive care nurses.

Aim

The aim of this study was to determine the effect of using a computer-assisted glycemia follow-up protocol on the nursing workload in intensive care unit.

\section{MATERIAL and METHODS}

\section{Study Design}

The study was conducted as a semi-experimental study between June- July 2017 in the 11-bed reanimation unit of the Anesthesiology and Reanimation clinic of a training and research hospital.

\section{Study Sample}

The study sample was composed of nurses working in the reanimation unit between June- July 2017, who volunteered to participate in the study. A total of 21 nurses work in the unit. Two nurses did not volunteer to participate in the study. The study sample consisted of 19 nurses who met the inclusion criteria and agreed to participate in the study. Study inclusion criteria: working in the reanimation unit, volunteered to participate in the study, knows how to use the computer-assisted glycemia follow-up protocol and knows how to use the written glucose follow-up protocol. Study exclusion criteria: did not volunteer to participate in the study.

\section{Data Collection Tools}

The study data were collected using an information form, the written glucose follow-up protocol, and the computerassisted glycemia follow-up protocol.

\section{Information Form}

The information form developed by the researchers as a result of the literature ${ }^{22-25}$ review consists of two parts. The first part is used to collect information on the sociodemographic and occupational characteristics of the nurses, and the second part collects information on the time nurses spend measuring for the glucose follow-up.

Written Glycemia Follow-up Protocol and ComputerAssisted Glycemia Follow-Up Protocol

Based on a literature review ${ }^{26-29}$, the glycemia follow-up protocol was created by intensive care doctors and nurses. This protocol was presented for review to five experts, each with experience in their own fields (chest diseases and intensive care specialist, anesthesia and intensive care specialist, internal medicine specialist nurse, endocrinology and metabolic diseases specialist). After the recommended corrections were carried out, the protocol was created in 2016 and, in the same year, the "ComputerAssisted Glycemia Follow-Up Protocol" was developed by computer programmers based on the written "Glycemia Follow-up Protocol".

In the protocol, with the patient's previous glycemia measurement value by comparing the last measured glycemia measurement value, appropriate follow-up and treatment are determined. In the protocol, the target 
glycemia range was determined between $120-180 \mathrm{mg} / \mathrm{dl}$. Also in the protocol, glycemia measurements $>300 \mathrm{mg} / \mathrm{dl}$ and $<120 \mathrm{mg} / \mathrm{dl}$, It is stated that the doctor should be informed with the treatment to be applied in the glycemia measurement values.

Results from a study using the computer protocol in 2016 showed that the patients were successfully managed in the target range for glucose follow-up, and the incidences of hypoglycemia and hyperglycemia were found to be very low. Some parts of the protocol that were implemented in the computer program are shown in Figure 1.

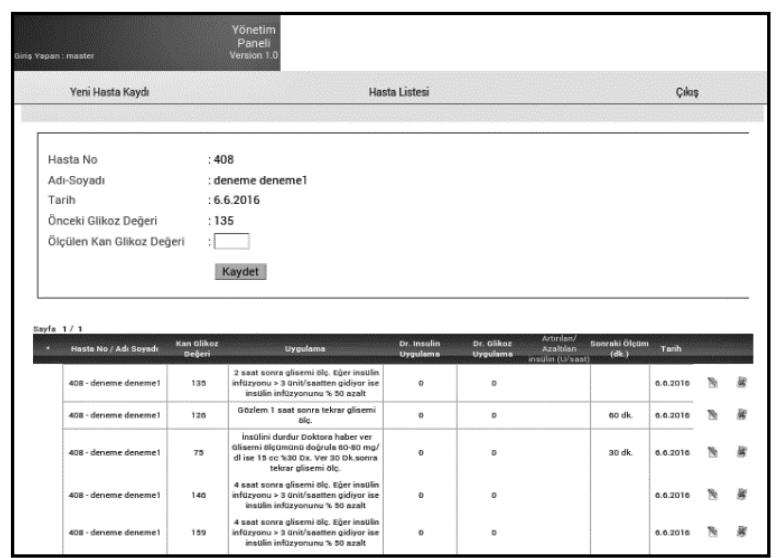

Figure 1. Computer-Guided Glucose Management Protocol: Patient's Glucose Values and Treatments

Questionnaire for the Intensive Care Nurses to Evaluate the Computer- Assisted and Written Glycemia Protocols

After reviewing the relevant literature, the questionnaire was prepared by the researchers in order to obtain the opinions of the intensive care nurses on the computerized and written glycemia protocol at the end of the study ${ }^{23,24,29,30}$. The questionnaire included questions which protocol for nurses is complex application, satisfied application and suitable application for intensive care unit. A total of 19 nurses filled out the questionnaire in about 10 minutes and the data was collected by the researcher and measured by the statistician.

\section{Data Collection}

Glycemia follow-up and treatment of patients treated in the reanimation unit are carried out using a computerized protocol. The computerized protocol is used by nurses via tablets at the patient's bedside. The written protocol is the computerized protocol in paper form.

Under the computerized protocol, the nurse enters the patient's glucose level into the program via a tablet after measuring it and applies the treatment required for the patient's glucose level according to the instruction in the computerized protocol.

In the written protocol, the nurse evaluates the patient's glucose level according to the written protocol and then applies the treatment required for the patient's glucose according to the order in the written protocol.
In both protocols, the treatment to be applied according to the patient's glucose value is the same. There are no differences in treatment between the protocols because the written protocol is simply the paper form of the computerized protocol. Patients who undergo glucose measurements are those who require glucose measurements for treatment. None of the patients were subjected to any extra glucose measurements for the study. First, for each nurse $(n=19)$, the time spent during the glycemia follow-up with the written protocol was recorded by two observing nurses using a stopwatch. The stopwatch was started as soon as the nurse had cleaned the finger of the patient with antiseptic solution and was stopped when the nurse decided on a treatment according to the written protocol based on the glucose level measured by the glucometer. The time that the nurse took to complete the process was recorded.

Second, for each nurse $(n=19)$, the time spent during the glycemia follow-up with the computerized protocol was recorded by two observing nurses using a stopwatch. The stopwatch was started as soon as the nurse had cleaned the finger of the patient with antiseptic solution and was stopped when the nurse decided on a treatment according to the computerized protocol based on the glucose level measured by the glucometer. The time that the nurse took to complete the process was recorded.

Also, nurses's inaccurate measurement in glycemic control using computerized and written protocol was recorded.

At the end of the study, a questionnaire was given to the participating nurses by the researchers in order to gather their opinions on the use of computerized and written protocols.

\section{Data Analysis}

Data on the effect of the computerized glucose management protocol on nursing workload were evaluated using the SPSS (Statistical Packages for the Social Sciences), Version 22. The statistical significance level was accepted as $\mathrm{p}<0.05$. Descriptive statistics were given as mean, standard deviation, frequency and percentage. In the comparison of continuous variables, $t$ test was used in case of normal distribution compliance.

\section{Ethical Consideration and Ethical Approvel}

Permission was obtained from the Clinical Research Ethics Committee of a training and research hospital (Decision Number: 2012-KAEK-15/1452) and the reanimation unit before the study. Written consent was obtained from the intensive care nurses that confirmed their willingness to participate in the study.

\section{Limitations}

Development process of the computerized and written protocol were applied in these intensive care unit. For this reason, the results of the study are limited to the unit and sample group in which the study was carried out. Because, only these intensive care nurses knew how to use the protocols.

\section{RESULTS}

The mean age of the nurses that participated in the study was $24.6 \pm 2.1$, all of them were female, $10 \%$ were married, 
$17 \%$ had a bachelor's degree, and $17 \%$ had $1-5$ years of work experience in the intensive care unit.

In our study, two observers were used to record the time that the nurses spent on glucose follow-up. The concordance correlation coefficient (Lin) ${ }^{31}$ was determined in order to decide which observer's results would be used in the analyses. In the evaluation of the time spent on the follow-up of glucose levels using the computer-guided protocol, the agreement between observers 1 and 2 was $99.5 \%$ while for the time spent using the written protocol there was $99.6 \%$ coherence between observers 1 and 2 . In this case, the results from observer 1 were used for all analyses as the observations for both observers 1 or 2 could be used for both protocols (Table 1).

Table 1. Interobserver Compatibility Analysis (Correlation Coefficient)

\begin{tabular}{|l|l|l|l|l|}
\hline Observers & Mean & Variance & Covariance & CCC \\
\hline Measurements with computerized protocol \\
\hline Observer 1 & 39.49 & 66.97 & \multirow{2}{*}{68.47} & $\% 99.5$ \\
\hline Observer 2 & 30.40 & 70.56 & & \\
\cline { 1 - 3 } Measurements with written protocol \\
\cline { 1 - 3 } Observer 1 & 42.78 & 100.94 & \multirow{2}{*}{100.42} & $\% 99.6$ \\
\hline Observer 2 & 42.70 & 100.68 & & \\
\hline
\end{tabular}

In our study, it was found that the intensive care nurses who performed glucose follow-up using the computerized protocol spent an average of $30.5 \pm 8.18$ seconds on the procedure compared to an average of $42.7 \pm 10.04$ seconds using the written protocol. The difference between the groups was statistically significant $(p<0.001)$ (Table 2$)$. The time spent using the written protocol for glucose follow-up was approximately 12 seconds longer, extending the duration by a ratio of 3 to 1 (30\%).

Table 2. Comparison of the Average Time Spent by Nurse in the Measurement of Glycemia by Computerized and Written Protocol

\begin{tabular}{|c|c|c|c|}
\hline & $\begin{array}{l}\text { Measurement } \\
\text { with } C P^{*} \\
(n=19) \\
\text { mean } \pm S D\end{array}$ & $\begin{array}{l}\text { Measurement } \\
\text { with WP* } \\
(n=19) \\
\text { mean } \pm S D\end{array}$ & $\begin{array}{l}\text { test } \\
\mathbf{p}\end{array}$ \\
\hline $\begin{array}{l}\text { Time (second) } \\
\text { spent by } \\
\text { nurses for } \\
\text { measuring } \\
\text { glycemia }\end{array}$ & $30.5 \pm 8.18$ & $42.7 \pm 10.04$ & $\begin{array}{l}5.307^{* *} \\
<0.001\end{array}$ \\
\hline
\end{tabular}

Of the 19 measurements carried out with the written protocol, two were inaccurate, while none of the measurements using the computer-guided protocol were incorrect. Although the error rate for the written protocol was found to be higher than that of the computer protocol (Table 3).
Table 3. Inaccurate Measurement Distribution in Glycemic Control Using Computerized and Written Protocol

\begin{tabular}{l|l|c|cc|}
\hline & \multicolumn{2}{|c|}{$\begin{array}{c}\text { Measurement with } \\
\text { CP* (n=19) }\end{array}$} & \multicolumn{2}{c|}{$\begin{array}{c}\text { Measurement with } \\
\text { WP* (n=19) }\end{array}$} \\
& n & \% & n & \% \\
\hline $\begin{array}{l}\text { Incorrect } \\
\text { measurement }\end{array}$ & 0 & 0 & 2 & 10.5 \\
${ }^{*}$ CP: Computerized protocol, WP: Written protocol.
\end{tabular}

Of the nurses, $78.9 \%$ stated that the written protocol was more complicated than the computer protocol. Of the nurses, $78.9 \%$ stated that the computerized protocol is the appropriate protocol for use in intensive care settings and $78.9 \%$ were satisfied with using the computerized protocol (Figure 2). Upon asking the intensive care nurses about their opinions on the computerized and written protocol, $84.2 \%$ stated that the use of the computer protocol was easy and $63.2 \%$ stated that the use of the written protocol was easy.

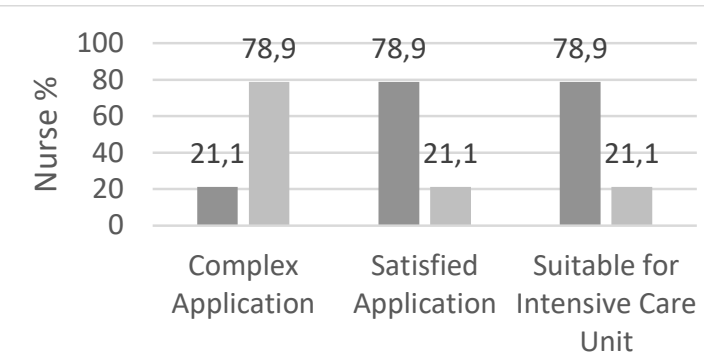

Computerized Protocol Written Protocol

Figure 2. Distribition of Intensive Care Nurses' Opinions About Computerized Protocol and Written Protocol $(n=19)$

\section{DISCUSSION}

One of the most important applications of safe medical practices in critical patient care in intensive care units is glucose follow-up. For glucose control, which has an important impact on mortality and morbidity in critically ill patients, it is necessary to establish easy-to-implement protocols in order to monitor blood glucose levels to prevent hypoglycemia and achieve acceptable blood glucose levels. Nurses working in intensive care units have high workloads. For this reason, the applications and protocols to be used in patient care should not increase the workload of the health personnel.

Computer-based decision support systems based on protocols are one of the most up-to-date approaches in clinical decision making. These systems make scientifically proven applications feasible and enable nurses to make the correct decision ${ }^{26,27}$. The computer-guided glucose management protocol that we developed is one such application. Various studies have evaluated the efficacy and safety of protocols and analyzed their effects on glycemic control21-24. But, studies evaluating the effect of computerized protocols on workload are limited worldwide. In a study by Davidson et al., the computer-guided insulin infusion protocol was approved by the nurses, the calculation time was less in the computerized protocol than in the written, and glucose was maintained at normal levels without developing hypoglycemia ${ }^{23}$. In a study by 
Olinghouse, calculation of the patient's insulin dose was found to take 30 seconds with the computer-guided protocol versus 2 minutes with the written protocol ${ }^{22}$. In our study, the glucose follow-up using the written protocol took about 12 seconds longer than using the computer-guided protocol and the duration was prolonged by a ratio of 3 to 1 (30\%).

The care of critical patients in intensive care is becoming increasingly complex as disease severity continues to increase. The number of patients requiring intensive care and increased clinical knowledge per bed also require increased evidence-based medical treatment and practices. Within the scope of safe medical applications, patient care is expected to include minimal medical errors and maximum quality ${ }^{28}$.

It is important for patient safety that the protocols used for critical patient care and treatment contain minimal medical errors. When examining the written and computerized protocol applications for glucose control of patients in our study, two out of 19 measurements in the glucose follow-up using the written protocol were erroneous, whereas no incorrect measurements were observed using the computerized protocol. In a study by Olinghouse, evaluated the computer protocol for safety reasons and found that there were no calculation errors when using the computer protocol, while there was an error rate of $38 \%$ with the written protocol ${ }^{22}$. When information technology is used appropriately and correctly, it can reduce the problems of human error and delays, especially in the field of health, as demonstrated by this study supports $21,22,25$.

Protocols used in patient care and treatment in intensive care units are expected to help ensure that patient care and treatment are successful, effective, and safe. Resistance from health personnel can prevent the benefits of computer technology applications in the field of health, especially in medical care, from being realized. It is therefore important that the practicing staff believe that the patients or the operation will benefit from the practice and, moreover, it is very important that the prepared applications and interfaces have easy-to-implement steps that do not increase staff workload and are not cognitively complicated. In the literature, studies have been published in which the users evaluated similar applications to our protocol $22,24,29,30$. In some of these studies, the nurses stated that the computerized protocols were more effective, safer, and easier to apply than the written protocols ${ }^{29,32}$. In our study, the nurses stated that the computer protocol was easier to use than the written protocol, that they were more satisfied with the implementation, and that it is more suitable for intensive care, and that the written protocol is more complicated than the computerized protocol.

\section{CONCLUSION}

The use of a computer-guided glucose management protocol in the follow-up of intensive care patients' glucose levels is more effective than the written protocol in terms of effective use of time in intensive care practice. Nurses found the computerized protocol easy to use, they were satisfied with the use, and believe that is a suitable protocol for intensive care. Thus, it will be beneficial to use a computerized glucose management protocol for glucose control of ICU patients.

Ethics Committee Approval: Permission was obtained from the Clinical Research Ethics Committee of a Training and Research Hospital (Date: 14 th June 2017, Decision Number: 2012-KAEK-15/1452).

Confict of Interest: There is no conflict of interest.

Funding: None.

Exhibitor Consent: Written consent was obtained from the intensive care nurses that confirmed their willingness to participate in the study.

Author contributions

Study design: OC,SK

Data collection: OC, SK

Literature search: OC, SK

Drafting manuscript: OC, SK

Acknowledgement: We would like to thank all nurses who participated to the study.

Etik Kurul Onayı (Kurul adı, tarih ve sayı no): Bir Eğitim ve Araştırma Hastanesinin Klinik Araştırmalar Etik Kurulu'ndan izin alınmıştır (Tarih: 14.06.2017, Karar No: 2012-KAEK15/1452).

Çıkar Çatışması: Çıkar çatışması yoktur.

Finansal Destek: Yoktur.

Katılımcı Onamı: Çalışmaya katılma isteyen yoğun bakım hemşirelerinden yazılı onam alındı.

\section{Yazar katkılar}

Araştırma dizaynı: ÖC, SK

Veri toplama: ÖC,SK

Literatür araştırması: ÖC,SK

Makale yazımı:ÖC,SK

Teşekkür: Çalışmaya katılan tüm hemşirelere teşekkür ederiz.

\section{REFERENCES}

1. Clain J, Ramar K, Surani SR. Glucose control in critical care. World J. Diabetes. 2015;6(9):1082-90.

2. Umpierrez GE, Isaac SD, Bazargan N, You X, Thaler LM, Kitabchi AE. Hyperglycemia: an independent marker of in-hospital mortality in patients with undiagnosed diabetes. J Clin Endocrinol Metab. 2002;87(3):978-82.

3. Hsu CW. Glycemic control in critically ill patients. World J. Diabetes. 2012;1(1):31-9.

4. Krinsley JS. Association between hyperglycemia and Increased hospital mortality in a heterogeneous population of critically ill patients. Mayo Clin Proc. 2003;78(12):1471-8.

5. Capes SE, Hunt D, Malmberg K, Gerstein HC. Stress hyperglycaemia and increased risk of death after myocardial infarction in patients with and without diabetes: systematic overview. Lancet. 2000;355(9206):773-8.

6. Falciglia $M$, Freyberg $R$, Almenoff $P L, D^{\prime}$ Alessio DA, Rende ML. Hyperglycemia-related mortality in critically ill patients varies with admission diagnosis. Crit Care Med. 2009;37(12):3001-9.

7. Kosiborod $M$, Inzucchi SE, Spertus JA, Wang $Y$, Masoudi FA, Havranek EP, et al. Elevated admission 
glucose and mortality in elderly patients hospitalized with heart failure. Circulation. 2009;119(14):1899907.

8. Kosiborod M, Rathore SS, Inzucchi SE, Masoudi FA, Wang $Y$, Havranek EP, et al. Admission glucose and mortality in elderly patients hospitalized with acute myocardial infarction implications for patients with and without recognized diabetes. Circulation. 2005;111(23):3078-86.

9. Van den Berg G, Wouters P, Weekers F, Verwaest C, Bruyninckx $F$, Schetz $M$, et al. Intensive insulin therapy in criticaly ill patients. $N$ Engl J Med. 2001;345(19):1359-67.

10. Van den Berghe G, Wilmer A, Milants I, Wouters PJ, Bouckaert B, Bruyninckx $F$, et al. Intensive insulin therapy in mixed medical/surgical intensive care units: benefit versus harm. Diabetes. 2006;55(11):3151-9.

11. Finney SJ, Zekveld C, Elia A, Evans TW. Glucose control and mortality in critically ill patients. JAMA. 2003;290(15):2041-7.

12. Pittas AG, Siegel R, Lau J. Insulin therapy for critically ill hospitalized patients: a meta-analysis of randomized controlled trials. Arch Intern Med. 2004;164(18):2005-11.

13. Krinsley JS. Effect of an intensive glucose management protocol on the mortality of critically ill adult patients. Mayo Clin Proc. 2004;79(8):992-1000.

14. Taylor BE, Schallom ME, Sona CS, Buchman TG, Boyle WA, Mazuski JE, et al. Efficacy and safety of an insulin infusion protocol in a surgical ICU. J Am Coll Surg. 2006;202(1):1-9.

15. Wilson M, Weinreb J, Soo Hoo GW. Intensive insulin therapy in critical care a review of 12 protocols. Diabetes Care. 2007;30(4):1005-11.

16. NICE-SUGAR Study Investigators, Finfer S, Chittock DR, Su SY, Blair D, Foster D, et al. Intensive versus conventional glucose control in critically ill patients. N Engl J Med. 2009;360(13):1283-97.

17. Preiser JC, Devos P, Ruiz-Santana S, Melot C, Annane D, Groeneveld J, et al. A prospective randomised multi-centre controlled trial on tight glucose control by intensive insulin therapy in adult intensive care units: the Glucontrol study. Intensive Care Med. 2009; 35(10):1738-48.

18. Cryer PE, Davis SN, Shamoon H. Hypoglycemia in diabetes. Diabetes Care. 2003;26(6):1902-12.

19. Seaquist ER, Anderson J, Childs B, Cryer F, Dagogo-Jack $S$, Fish L, et al. Hypoglycemia and diabetes: a report of a workgroup of the American Diabetes Association and the Endocrine Society. Diabetes Care. 2013;36(5):1384-95.

20. Tarnow-Mordi WO, Hau C, Warden A, Shearer AJ. Hospital mortality in relation to staff workload: a 4year study in an adult intensive-care unit. Lancet. 2000;356(9225):185-9

21. Newton CA, Smiley D, Bode BW, Kitabchi AE, Davidson PC, Jacops $S$, et al. A comparison study of continuous insulin infusion protocols in the medical intensive care unit: computer- guided vs. column-based algorithms. J Hosp Med. 2010;5(8):432-7.

22. Olinhouse C. Development of a computerized intravenous insulin application (Autocal) at Kaiser Permanente Northwest, integrated into Kaiser Permanente Healthconnect: impact on safety and nursing workload. Perm J. 2012;16(3):67-70.

23. Davidson PC, Steed R, Bode BW, Hebblewhite HR, Prevosti L, Cheekati V. Use of a computerized intravenous insulin algorithm within a nurse-directed protocol for patients undergoing cardiovascular surgery. J Diabetes Sci Technol. 2008;2(3):369-75.

24. Correa TD, Pereira de Almeida F, Cavalcanti AB, Pereira AJ, Silva E. Assessment of nursing perceptions of three insulin protocols for blood glucose control in critically ill patients. Einstein. 2012;10(3):347-53.

25. Canbolat O, Kapucu S, Kılıçkaya O. Comparison of routine and computer guided glucose management for glycemic control in critically ill patients. Crit. Care Nurse. 2019;39(4):20-7.

26. Sucu G, Dicle A, Saka O. Decision making in clinical nursing: decision-making models and affecting factors. HEAD. 2012;9(1):52-60.

27. Anderson JA, Wilson P. Clinical decision support systems in nursing. computers, informatics. Nursing. 2008;26(3):151-8.

28. Kollef $\mathrm{MH}$, Micek ST. Using protocols to Improve patient outcomes in the intensive care unit: focus on mechanical ventilation and sepsis. Semin Respir Crit Care Med. 2010;31(1):19-30.

29. Boord JB, Sharifi M, Greevy RA, Griffin M, Lee VK, Webb TA, et al. Computer-based insulin infusion protocol improves glycemia control over manual protocol. J Am Med Inform Assoc. 2007;4(3):278-87.

30. Cavalcanti AB, Silva E, Pereira AJ, Pereira AJ, CaldeiraFilho $\mathrm{M}$, Almeida $\mathrm{FP}$, et al. A randomized controlled trial comparing a computer-assisted insulin infusion protocol with a strict and a conventional protocol for glucose control in critically ill patients. J Crit Care. 2009;24(3):371-8.

31. Lin's concordance correlation coefficient. [Internet]. 2018 [Erişim Tarihi 05 Temmuz 2018]. Erişim adresi: https://ncss-wpengine.netdna-ssl.com/wpcontent/themes/ncss/pdf/Procedures/PASS/Lins_Co ncordance_Correlation_Coefficient.pdf

32. Goldberg PA, Siegel M, Sherwin RS, Halickman JI, Lee M, Bailey VA, et al. Implementation of a safe and intensive care unit. Diabetes Care. 2004;27(2):461-7. 